\title{
Cancer mortality in the asphalt industry: a ten year follow up of an occupational cohort
}

\author{
EVA S HANSEN
}

From the Institute of Community Health, University of Odense, DK-5000 Odense C, Denmark

ABSTRACT A historical cohort study was conducted to study the possible risk of cancer associated with exposure to asphalt. Altogether 1320 unskilled workers employed in the asphalt industry werge followed up over a ten year period and compared with 43024 unskilled men in terms of cause specifio mortality. Both groups were identified from census records and followed up by an automatic recorg link that had been established previously between the census register, National Register, and Deat Certificate Register. The cancer mortality was significantly increased in asphalt workers aged 45 oib more, when five years' latency from enrolment into the study was allowed for (SMR for cancer: 15 $\dot{\Phi}_{0}$ 95\% confidence interval: 106-228). Non-significant increases were seen for respiratory, bladder, and digestive cancers but a significant increase was seen for brain cancer $\left(\mathrm{SMR}=500,95 \% \mathrm{CI}: 103^{\mathrm{Z}}\right.$ 1461). Components of asphalt fumes may have been important to the observed association between risk of cancer and employment in the asphalt industry.

Workers may be exposed to bitumen fumes during the manufacture of asphalt mixes and roofing materials. Depending on the manufacturing process, there may be additional exposure to other substances including silica dust, organic solvents, acid amines, coal tars, and fungicides.

A possible association with the risk of cancer is suspected regarding exposure to bitumen fumes. A strong carcinogenic effect from condensed bitumen fumes has been shown recently by skin application to mice.' The yield of malignant neoplasms in mice exposed to bitumen fume condensate almost equalled that of the positive control group, which was painted with condensed coal tar fumes. Previously, epidemiological studies have shown increased cancer mortality among roofers who are exposed to bitumen fumes. Menck and Henderson used registry data to estimate the lung cancer mortality for several occupational groups in Los Angeles County and found that the lung cancer mortality for roofers was almost five times that of the general population. ${ }^{2}$ Another study on the mortality of roofers was carried out by Hammond and co-workers who conducted a 12 year follow up of a cohort of United States roofers identified from union files. ${ }^{3}$ Among long term employed roofers, they found an increased mortality from malignant neoplasms of the buccal cavity and

Accepted 19 September 1988 pharynx, digestive organs, respiratory system, proș0 tate gland, bladder and skin, and from leukaemia. Thi studied groups of roofers, however, might have ben exposed to both coal tar and bitumen fumes ${ }^{23}$ sodie clear conclusions could be drawn regarding the p $\bar{s} s=$ ible association between exposure to bitumen fumere and the risk of cancer.

The present study was designed to investigate the mortality pattern in the Danish asphalt industry, in particular to examine the potential correspondence of this pattern with that seen in the studies on roofers mortality.

\section{Subjects and methods}

The research design was that of a historical cohor study composed of exposed and unexposed workers asphalt workers, the exposed part of the cohort, were compared with the unexposed group of unskille $\$$ workers in terms of cause specific mortality.

The members of the study cohort were identified. from the files of a nation wide census carried out in Denmark on 9 November 1970. On this occasion, seff reported occupation, trade industry, and employments on the day of census were recorded for all Danish inhabitants aged over 14. These data were used tQ select the people included in the study.

The study was comprised exclusively of unskille male workers between 15 and 74 who were occupationally active on the day of the census. 
Unskilled men employed in the asphalt industry (at asphalt plants, roofing felt plants, or one tar plant) comprised the exposed group and the unexposed part of the cohort included unskilled male workers in service trades (38\% of the total comparison group), agriculture and forestry (36\%), and specific light industries $(26 \%)$. Table 1 shows the number of exposed and unexposed individuals by ten year age groups.

The Danish National Bureau of Statistics has established an automatic record link between the 1970 census register, the National Register, and the Death Certificate Register (publications No 37 (1979) and No 41 (1985) from the Danish National Bureau of Statistics, both in Danish). Accordingly, any population identified in the 1970 census records may be automatically followed up with regard to cause specific mortality within ten years of 9 November 1970. For reasons of confidentiality, however, the National Bureau of Statistics releases only anonymous, grouped data to a claimant. The automatic record link system was used to trace the members of the cohort and to ascertain the cause of death of those who had died. The cohort was traced to 9 November 1980 or until death or emigration before this date. Dead individuals, emigrants, and those lost to follow up contributed person-years at risk until the day of death, date of emigration, or last day of notification in the National Registry, respectively. For those who had died, the study used the notified underlying cause of death. Expected numbers of deaths among the asphalt workers were calculated from the death rates of the comparison group of unskilled men and the number of person-years at risk accumulated by the asphalt workers.

In addition, the asphalt workers were compared with the occupationally active 1970 census population in terms of total mortality, cancer mortality, and mortality due to cardiovascular disease.

For statistical evaluation, observed numbers over 100 were assumed to follow a normal distribution (Yates's correction was used). A Poisson distribution was assumed for smaller numbers. The death rates of the comparison group were assumed to be uninfluenced by random variation.

Table 1 Number of individuals in the cohort by age and exposure

\begin{tabular}{lcc}
\hline $\begin{array}{l}\text { Age on } \\
\text { November } 1970\end{array}$ & $\begin{array}{l}\text { Asphalt } \\
\text { workers }\end{array}$ & $\begin{array}{l}\text { Comparison } \\
\text { group }\end{array}$ \\
\hline $15-24$ & 197 & 8407 \\
$25-34$ & 303 & 8030 \\
$35-44$ & 242 & 7421 \\
$45-54$ & 301 & 8864 \\
$55-64$ & 240 & 8592 \\
$65-74$ & 37 & 1710 \\
Total & 1320 & 43024 \\
\hline
\end{tabular}

Table 2 Follow up data for asphalt workers and the comparison group: deaths and emigrations within the first and second five year period of the study, respectively

\begin{tabular}{lcc}
\hline & $\begin{array}{l}\text { No of } \\
\text { deaths }\end{array}$ & $\begin{array}{l}\text { No of } \\
\text { emigrations* }\end{array}$ \\
\hline Asphalt workers: & & \\
lst five year period & 34 & 12 \\
2nd five year period & 79 & 13 \\
Total & 113 & 25 \\
Comparison group: & 1505 & 611 \\
1st five year period & 2306 & 301 \\
2nd five year period & 3811 & 912 \\
Total &
\end{tabular}

*Includes those lost to follow up.

\section{Results}

A total of 113 asphalt workers and 3811 members of the comparison population died within the ten year period of follow up (table 2).

Tables 3 and 4 show the cause specific standardised mortality ratios for comparison with unexposed, unskilled men. According to the ten year data (table 3), the cancer mortality of the asphalt workers was slightly raised, mainly because of an increased number of deaths from malignant neoplasms of the respiratory tract or the urinary bladder. In addition, the mortality from ischaemic heart disease was slightly raised, whereas a significant decrease was seen for all other natural deaths except those due to cancer or ischaemic heart disease. When the analysis was restricted to the 6th to 10th years of follow up (table 4), the mortality differences were more pronounced than from the ten year data. In particular, the asphalt workers' mortality from cancer was significantly increased within the last five years of the study (table 4). In addition to an increased number of deaths from respiratory cancer or bladder cancer, an excessive number of digestive cancers was seen. Three cases of brain cancer were observed among the asphalt workers, significantly exceeding the expected number (SMR $=500,95 \%$ CI for SMR:103-1461).

Table 3 Asphalt workers' mortality from 1970 to 1980 compared with that of unskilled men: observed number of deaths (Obs) and SMR for men aged 45 or more

\begin{tabular}{lrcl}
\hline $\begin{array}{l}\text { Cause of death } \\
\text { (ICD-8) }\end{array}$ & Obs & SMR & $(95 \% C I)^{*}$ \\
\hline Malignant neoplasms (140-209): & 37 & 123 & $(87-170)$ \\
$\quad$ Respiratory cancer (160-163) & 16 & 143 & $(82-232)$ \\
Bladder cancer (188) & 5 & 301 & $(98-703)$ \\
Other malignant neoplasms & 16 & 93 & $(53-151)$ \\
Ischaemic heart disease (410-414) & 39 & 113 & $(80-155)$ \\
Other diseases & 16 & 57 & $(32-92)$ \\
External causes (E000-E999) & 12 & 131 & $(68-229)$ \\
Total & 104 & 102 & $(80-131)$ \\
\hline
\end{tabular}

*95\% Confidence interval. 
Table 4 Asphalt workers' mortality from 1975 to 1980 compared with that of unskilled men: observed number of deaths (Obs) and SMR for men aged 45 or more. A five year latency period from enrolment into the cohort was required

\begin{tabular}{lrcl}
\hline $\begin{array}{l}\text { Cause of death } \\
\text { (ICD-8) }\end{array}$ & Obs & SMR & $(95 \% C I)$ \\
\hline Malignant neoplasms (140-209): & 29 & 159 & $(\mathbf{1 0 6 - 2 2 8 )}$ \\
$\quad$ Digestive cancer (150-159) & 6 & 157 & $(58-343)$ \\
Respiratory cancer (160-163) & 11 & 152 & $(76-271)$ \\
Bladder cancer (188) & 3 & 291 & $(60-851)$ \\
Other malignant neoplasms & 9 & 145 & $(66-276)$ \\
Ischaemic heart disease (410-414) & 29 & 131 & $(88-189)$ \\
Other diseases & 8 & 44 & $(19-88)$ \\
External causes (E000-E999) & 8 & 167 & $(72-329)$ \\
Total & 74 & 116 & $(91-146)$ \\
\hline
\end{tabular}

Comparison with the occupationally active 1970 census population gave less detailed but only slightly different results (table 5).

\section{Discussion}

The results seem to indicate that employment in the Danish asphalt industry has been associated with an increased risk of respiratory, digestive, and bladder cancers. Before any conclusions can be made, however, it is first necessary to consider potential sources of error in the study.

The mortality of the asphalt workers was compared with that of unskilled men in occupations without exposure to carcinogens. The occupational groups for comparison were selected to resemble the group of asphalt plant workers in terms of work related demands on physical strength and fitness, social class, and geographic distribution. Accordingly, the two groups were made as compatible as possible in every relevant respect except occupational exposure to asphalt. In particular, it was hoped that the so called healthy worker effect could be eliminated by using a handpicked comparison group of unskilled workers. Apart from stratification for age and calendar time, no further bias control was practicable. The possibility still exists, however, that life style habits differed between the asphalt workers and the unskilled workers with whom they were compared. Possible differences in smoking habits would be of particular interest, because smoking is associated with increased risk of

Table 5 Asphalt workers' mortality compared with that of occupationally active men: SMR for those aged 45 or more

\begin{tabular}{|c|c|c|}
\hline $\begin{array}{l}\text { Cause of death } \\
(I C D-8)\end{array}$ & $\begin{array}{l}1970-80 \\
\operatorname{SMR}(95 \% \mathrm{CI})\end{array}$ & $\begin{array}{l}1975-80 \\
S M R(95 \% C I)\end{array}$ \\
\hline \multicolumn{2}{|c|}{$\begin{array}{l}\text { Malignant neoplasms }(140-209) 120(85-166) \\
\text { Cardiovascular disease }(390-58) 104(7-138)\end{array}$} & $\begin{array}{l}155(104-223) \\
113(78-158)\end{array}$ \\
\hline Total & $104(84-130)$ & $120(94-151)$ \\
\hline
\end{tabular}

respiratory cancer, bladder cancer, and ischaemic heart disease-diseases which occurred excessivelg among the asphalt workers. Smoking is extreme prevalent among Danish men, however, and smoking habit differences are likely to have caused only a minom degree of positive confounding. ${ }^{4}$

Referring to the concept introduced by Hernberg the actual cohort study was rather insensitive. On occupationally active and therefore healthy peopes were enrolled in the cohort and the follow up wis rather short. Within the first five years of follow ups only a few deaths from cancer occurred among the asphalt workers, whereas 29 deaths from cancer occurred in the subsequent five year period. This reflects not only the aging of the cohort members buin may indicate that an effective health selection wos operating among the asphalt workers before the identification of the study groups; workers whis develop symptoms of a subsequently fatal disease ario likely to be sorted out at an early stage. One resuif would be that the first years of follow up would yield only sparse information. It would have been desirable to extend the follow up period beyond ten years but this was not practicable. Another aspect which affect the sensitivity of the study is defining and ascertainiris exposure categories. The only criteria for an individuan to be included into either category were his occupation and being employed on the day of census; in the context "exposure" means potential occupatiolial exposure at the time of enrolment into the study. the purpose of studying cancer in relation to suspecte risk factors, cumulated exposure would be much more relevant to consider than point-in-time exposure. The employed definition of exposure dilutes the contrase between the exposed and unexposed study populab tions. The exposed category may include those wit $\bar{B}$ short term, low, or even no exposure and the unex posed category may include those previously expose $\overrightarrow{\text { P. }}$. The mortality differences actually observed between asphalt workers and the comparison group may therefore refer only to minor differences in exposure-

With this in mind, it is notable that a significan increase in cancer mortality was observed from 1975 to 1980 among asphalt workers aged 45 or more. The mortality pattern observed among asphalt plant worko ers resembled that previously observed amon? roofers. ${ }^{23}$ Both roofers and asphalt plant workers a

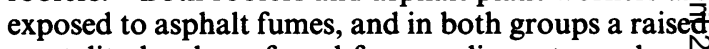
mortality has been found from malignant neoplasm of the respiratory system, digestive organs, and urino ary bladder. The increased mortality seen for these cancer sites makes it relevant to look for particulate aut pollution as a possible "explanation," and it is tempts ing to suggest that asphalt fumes might be significant particularly as condensed asphalt fume has been foun to be strongly carcinogenic to rodents. 'Asphalt fumie 
constitutes a disperse aerosol that contains cracking products from the heated bitumen, as well as light components of the bitumen itself. After inhalation of bitumen fumes, the mucous membranes of the respiratory tract may be exposed to toxic substances in the fumes. Because of respiratory mucociliary clearance mechanisms, most of the inhaled particles are conveyed to the digestive tract. Toxic substances in the asphalt fumes may then reach not only the digestive mucosa but may become eligible for uptake. The substances may enter the bloodstream, be metabolised, and be excreted in the urine.

Thus, from a biological point of view, exposure to asphalt fumes may well be associated with increased risk of malignant neoplasms originating from the respiratory, digestive, or urinary mucosa.

I thank Otto Andersen, National Bureau of Statistics, for providing possibilities to make use of census records.
This work was supported by grants from the Danish National Anti-Cancer League and the Health Insurance Foundation.

\section{References}

1 Thayer PS, Menzies KT, von Thuna PC. Roofing asphalts, pitch and UVL carcinogenesis-report. Springfield Va: National Technical Information Services, 1981. (US Department of Health and Human Services (PB83-134767.))

2 Menck HR, Henderson BE. Occupational differences in rates of lung cancer. J Occup Med 1976;18:797-801.

3 Hammond EC, Selikoff IJ, Lawther PL, Seidman H. Inhalation of benzopyrene and cancer in man. Ann NY Acad Sci 1976; 271:116-24.

4 Axelson 0 . Aspects on confounding in occupational health epidemiology. Scand J Work Environ Health 1978;4:85-9.

5 Hernberg S. "Negative" results in cohort studies-how to recognize fallacies. Scand J Work Environ Health 1981;7, suppl 4: 121-6. 